Jurnal Indonesia Sosial Teknologi: p-ISSN: 2723 - 6609

e-ISSN : 2745-5254

Vol. 2, No. 5 Mei 2021

\title{
STRATEGI ADAPTASI BERBASIS MODAL SOSIAL PETANI GARAM DALAM MENGHADAPI KEBIJAKAN IMPOR GARAM
}

\section{Muhammad Ilman Naafi'a}

Pendidikan Sosiologi, SPs Universitas Pendidikan Indonesia

Email: ilmansosio@upi.edu

\section{Abstract}

Salt farmers who feel from the high import of salt are experiencing many problems such as debt, mortgaging securities, low income and a large supply of unsold salt. From the impact experienced by salt farmers, they must be able to adapt the reality of what is happening today based on their social capital. The purpose of this study is to find out how the social capital-based adaptation strategy of salt farmers in dealing with the high salt import policy in Rawaurip Village, Pangenan District, Cirebon Regency. This research uses a qualitative approach and a case study method. In this study, researchers collected data using observation, interview and documentation study techniques. The results showed that there are three typologies of salt farmers, including salt farm workers, salt farmers who own ponds and salt farmers who own salt factories. When the salt import policy is high, it creates a cheap price of Rp. 200, - / kg. At each level, salt farmers carry out different adaptation strategies including external actions such as looking for work outside the salt field, adaptive action, namely trying to adjust to cheap salt prices by negotiating, and subsistence ethics, namely salt farmers taking safe actions by reducing expenditure. In addition, this adaptation strategy is based on Putnam's social capital, (1) the external actions of salt farmers are very close to the beliefs held by salt farmers, a norm that is upheld. (2) The adaptive action of salt farmers is closely related to the existence of social networks among salt farmers, and (3) the ethical actions of subsistence are related to norms and social networks with the existence of patron-client relationships. So that it creates the survival of salt farmers in the face of cheap salt prices due to high salt imports.

Keyword: Adaptation Strategies, Social Capital, Salt Farmers, Salt Import Policy.

\footnotetext{
Abstrak

Tujuan dari penelitian ini mengetahui bagaimana strategi adaptasi berbasis modal sosial pada petani garam dalam menghadapi kebijakan impor garam yang tinggi di Desa Rawaurip, Kecamatan Pangenan, Kabupaten Cirebon. Penelitian ini memakai pendekatan kualitatif dan metode studi kasus. Peneliti mengumpulkan data dengan menggunakan teknik observasi, wawancara dan studi dokumentasi. Hasil penelitian menunjukkan bahwa petani garam terdapat tiga tipologi petani garam diantaranya, buruh tani garam, petani garam pemilik tambak dan petani garam yang memiliki pabrik garam. Ketika kebijakan impor garam yang tinggi, sehingga menciptakan harga yang murah yaitu Rp. 200,-/kg. Disetiap level petani garam melakukan
} 
strategi adaptasi yang berbeda diantaranya tindakan eksternal seperti mencari pekerjaan diluar bidang garam, tindakan adaptif yaitu mencoba untuk menyesuaikan dengan harga garam yang murah dengan bernegosiasi, dan etika subsistensi yaitu petani garam melakukan tindakan aman dengan menekan pengeluaran. Ditambah lagi, strategi adaptasi ini berbasis modal sosial Putnam diantaranya (1) tindakan eksternal petani garam sangat erat dengan kepercayaan yang dimiliki oleh petani garam, norma yang dijunjung. (2) Tindakan adaptif petani garam sangat erat dengan adanya jaringan sosial antar petani garam, dan (3) tindakan etika subsistensi berkaitan dengan norma dan jaringan sosial dengan adanya hubungan patron-klien. Sehingga tercipta kebertahanan hidup petani garam dalam menghadapi harga garam yang murah akibat impor garam yang tinggi.

Kata Kunci : Impor Garam; Modal Sosial; Petani Garam; Strategi Adaptasi.

\section{Pendahuluan}

Periode Juli, tahun 2019, "impor garam terlampau berlebihan dan adanya kebocoran" menurut Menteri Kelautan, Susi Pudjiastuti (kompas.com). Hal ini terjadi karena pengawasan kuota impor garam masuk ke Indonesia terlalu berlebihan oleh Kemendagri dan Kemenperin karena sudah dialihkan, sehingga lembaga Kementerian Kelautan dan Perikanan yang biasanya mengontrol kuota impor tidak bisa mengatur kuota impor garam kembali. Kebijakan ini yang merusak harga garam di Desa Rawaurip, Kecamatan Pangenan, Kabupaten Cirebon.

Desa Rawaurip merupakan desa yang memiliki cukup luas tanah yang dijadikan tambak garam. Pemanfaatan lahan yang begitu luas oleh masyarakat dibantu oleh pemerintah melalui adanya Bumdes. Pemerintahan Desa membantu petani garam demi menjaga hasil garam yang berkualitas dan tidak menghilangkan mata pencaharian. Menurut Dinas Perikanan dan Kelautan Kabupaten Cirebon (2018), Desa Rawaurip memiliki luas lahan tambak garam 300 hektar yang mampu memproduksi 4.939 ton perperiode panen.

Visi dan misi Kabupaten Cirebon secara eksplisit menjelaskan adanya pembangunan - pembangunan yang sesuai dengan potensi alam yang tersedia pada web Kabupaten Cirebon. Bila melihat pada realita yang terjadi, bukan sesuai potensi alam, pembangunan pabrik yang jauh dari potensi alam dibentuk. Tambak garam dan lahan sawah mulai terkikis akibat mengularnya pabrik disepanjang jalan pantura. Ditambah lagi, adanya pembuatan PLTU dari Desa kanci menuju Desa Pengarengan.

Pelaku usaha tambak garam pada masyarakat Desa Rawaurip merupakan mata pencaharian yang cukup penting karena hampir $300 \mathrm{H}$ tambak garam ini ada pada desa ini, tetapi pada kenyataannya ketika keran impor garam dibuka lebar dan perhatian pemerintah terhadap garam lokal bisa berkembang sangat kurang. Hal ini menghasilkan dampak sosial bagi petani garam dalam menafkahi keluarga dan menjalankan kehidupan sosialnya. Tidak sedikit petani garam beralih pada mata pencaharian lain, karena masalah yang dihadapinya antara lain, kurangnya perhatian pemenerintah, hingga mutu 
garam rendah kalah saing dengan garam impor, harga garam rerndah dan keran impor yang sangat lebar.

Upaya petani garam dalam beradaptasi memiliki proses yang pelik, kondisi yang cepat berubah karena alam tidak diprediksi, sehingga suatu hal yang mutlak untuk menentukan strategi adaptasi yang tepat untuk melangsungkan hidup. Kekhawitaran yang mendera petani garam merupakan konsekuensi logis. (Coleman, 2011) mengemukakan teori etika subsistensi yang fokus analisisnya pada petani di Asia tenggara. Analisisnya mengemukakan bahwa para petani didera kekhawatiran tentang kelaparan karena terjadi gagalnya panen yang merugikan mereka, sehingga terjadi kelaparan pada keluarga. Hal ini yang menyebabkan para petani garam harus mengatur siasat untuk beradaptasi dengan segala kemungkinan yang akan terjadi. Dalam tawaran Scoot, strategi yang dikemukan ialah menahan diri dan membatasi modal dalam melakukan aktifitas ekonomi bagi para petani.

(Helmi \& Satria, 2013) meneliti tentang bagaimana strategi adaptasi nelayan terhadap perubahan ekologi yang terjadi di kalimantan selatan. Menitik beratkan pada upaya adaptasi nelayan tanpa memaksimalkan upaya modal sosial dalam mengadaptasi perubahan ekologi. Sejalan dengan adanya perubahan, (Azizah et al., 2017) meneliti peralihan lahan pertanian bendungan jatigede yang menyebabkan petani harus beradaptasi sosial-ekonomi. Para petani melakukan beberapa tindakan adaptasi dalam mensiasati peralihan lahan akibat adanya pembuatan bendungan jatigede.

Penulis ingin meneliti strategi adaptasi berbasis modal sosial pada petani garam sebagai kebaharuan penelitian yang belum dilakukan bagi petani garam. Unsur modal sosial pada masyarakat yang mampu memberikan dampak besar bagi komunitas. Diyakini modal sosial berkaitan pada dimensi institusi, hubungan komunikasi yang tercipta, nilai dan norma yang membentuk kualitas serta kuantitas kerekatan sosial dalam masyarakat. Hal ini sebagai dasar perekat dalam menjaga equilibrium dan kesatuan anggota masyarakat (Bank Dunia, 2011).

Dimensi modal sosial berkembang pada suatu komunitas yang didalamnya menyepakati nilai dan norma serta adanya pola-pola interaksi sosial dalam mengatur kehidupan keseharian individu. Pendapat lain menyatakan (Fukuyama, 2002) bahwa nilai dan norma yang disepakati bersama sebagai referensi bersikap, tindakan dan berperilaku yang otomatis menjadi modal sosial. Modal sosial secara sebenar hanya nilai dan norma yang dipercayai bersama dibangkitkan oleh kepercayaan. Kepercayaan ini merupakan pondasi awal bagi masyarakat untuk bersikap, keteraturan, kejujuran dan perilaku kooperatif yang muncul dari dalam sebuah komunitas masyarakat yang didasarkan pada nilai dan norma yang dianut bersama oleh para anggotanya.

Terlihat dalam perkembangan kebijakan impor garam pada modal sosial petani garam dilihat melalui strategi adaptasi dan hubungan dengan kebijakan impor garam. Adanya intensitas kebijakan garam dari tahun ke tahun semakin tidak terkontrol, eksistensi modal sosial yang dimiliki petani garam berkaitan dengan kerjasama dan kepercayaan, norma dan jaringan sosial. Hal ini menunjukan bahwa adanya kaitan 
antara pengaruh kebijakan impor garam dengan strategi adaptasi dan modal sosial pada petani garam.

Petani garam Desa Rawaurip yang memiliki banyaknya tekanan yang membuat mereka harus beradaptasi dengan segala keterbatasan. Sehingga mereka harus memanfaatkan jaringan sosial yang dibangun antar individu dalam masyarakat. Modal sosial secara eksistensial tidak memiliki wujud, karena diwujudkan dalam relasi diantara individu dalam rangka untuk memudahkan tindakan mereka (Coleman, 2011; 420). Modal sosial muncul ketika norma dan kepercayaan antar individu dalam masyarakat selalu ditaati satu sama lain. Tidak pernah terjadi memanfaatkan kepercayaan untuk tujuan negatif yang diberikan oleh anggota masyarakat lainnya. Dapat disimpulkan secara sederhana, modal sosial merupakan perwujudan dari kepercayaan, norma dan jaringan sosial yang saling berkaitan membentuk suatu kesatuan yang bertujuan menciptakan kehidupan yang teratur dalam masyarakat (Coleman, 2011; 415).

Sehingga dari latarbelakang diatas dapat diambil judul "Strategi Adaptasi, Modal Sosial Dan Dampak Sosial Petani Garam Dalam Menghadapi Kebijakan Impor Garam ", peneliti mencoba menggali lebih mendalam tentang petani garam di Desa Rawaurip, Kecamatan Pangenan, Kabupaten Cirebon. Tujuan agar petani garam bisa memaksimalkan modal sosial yang dimiliki dalam beradaptasi menghadapi kebijakan impor garam yang tinggi.

\section{Metode Penelitian}

Penelitian ini berfokus pada analisis strategi adaptasi berbasis modal sosial pada petani garam dalam kebijakan impor garam di Desa Rawaurip, kecamatan Pangenan, Kabupaten Cirebon. Penelitian menggunakan pendekatan kualitatif dan metode studi kasus. Pengumpulan data dilakukan dengan teknik observasi, wawancara, dan analisis dokumentasi (Sugiyono, 2013). Informan pokok merupakan masyarakat Desa Rawaurip yang menjadi Petani garam. Informan penelitian ini terdiri dari 8 informan pokok dan 2 informan kunci. Informan pokok ialah petani garam yang terbagi menjadi tiga tipologi (Buruh tani garam, petani garam pemilik tambak, dan petani garam pemilik pabrik garam) dan informan kunci ialah ketua koperasi petani garam dan penyuluh sosial dinas kelautan dan perikanan (Creswell, 2016).

\section{Hasil dan Pembahasan}

Dalam realitas masyarakat agraris tentu memiliki keunikan profesi yang dilihat dari lingkungannya. Masyarakat yang bermukim digaris pantai utara khususnya, memiliki profesi yang mayoritas nelayan, tambak ikan dan petani garam. Meski heterogenitas sudah merebak karena zaman sudah modern, namun profesi tradisional masih eksis karena peran pendidikan sebagai faktor penentu belum maksimal. Terdapat beragam dinamika masyarakat petani garam yang terdampak dari merugikan sampai memanfaatkan keuntungan. Adapun gambaran petani garam diantaranya, pertama, 
buruh tani garam. Kedua, Petani garam yang memiliki tambak garam. Ketiga, petani garam yang memiliki pabrik garam. Dalam kehidupan masing - masing petani garam memiliki perbedaan, lihat Tabel 1 .

Tabel 1. Klasifikasi Petani Garam

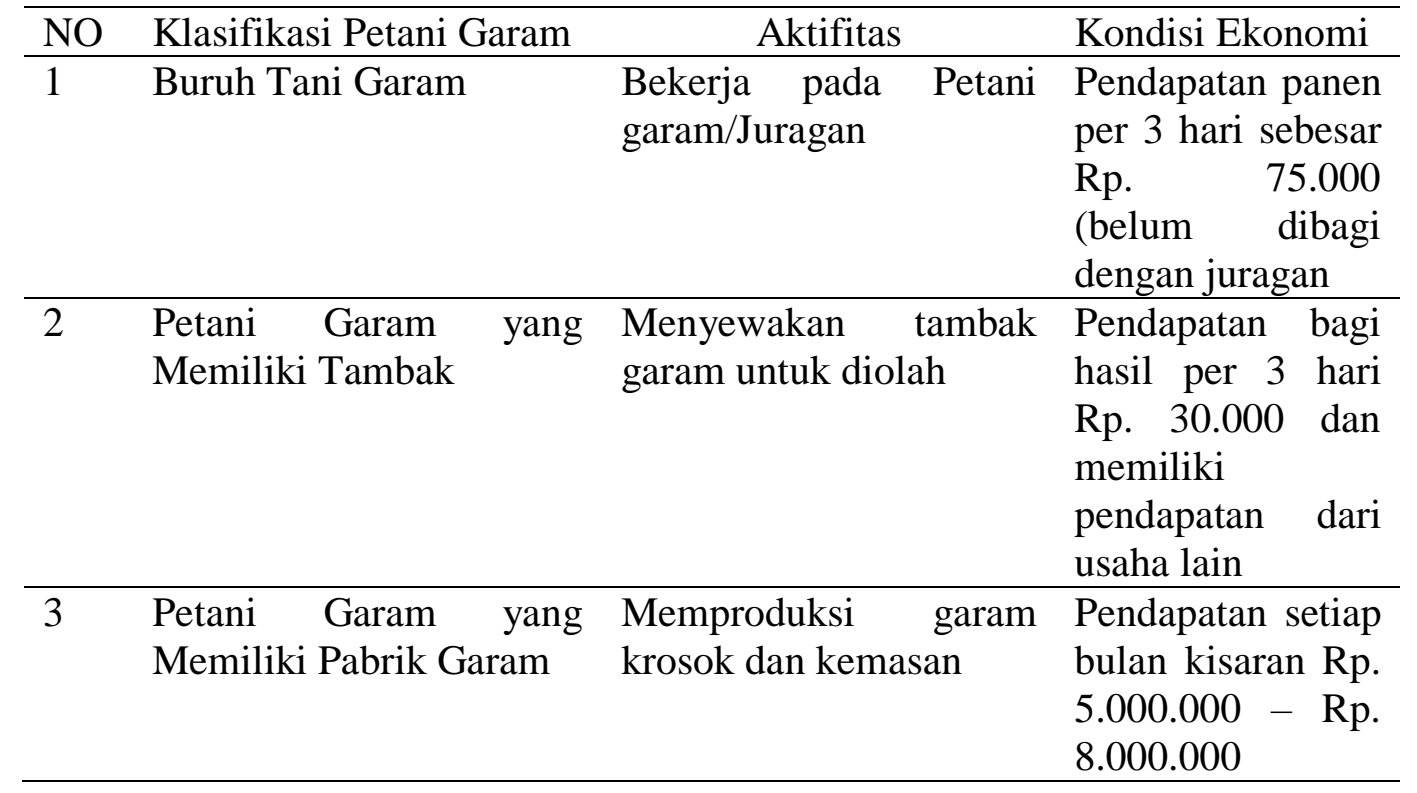

Kebijakan impor garam yang tinggi memaksa garam lokal berkompetisi dengan garam impor yang tidak memiliki dukungan dari sektor kementerian perdagangan dan kementerian perindustrian. Kementerian perdangan mengesahkan kebijakan impor garam berdasarkan kementerian perindustrian yang lembaga tersebut tidak melihat stock on hand secara langsung di masyarakat.

"garam lokal indonesia masih memiliki NaCL yang rendah dibandingkan garam impor, oleh karena itu kebijakan impor diambil untuk memenuhi kebutuhan garam industri untuk pabrik - pabrik makanan yang memiliki standar garam yang tinggi".

Dengan adanya impor garam tinggi ini berdampak pada beragam hal bagi petani garam di Desa Rawaurip, Kecamatan Pangenan, Kabupaten Cirebon. adapun dampak yang dirasakan oleh para petani yaitu berhutang, menggadaikan surat berharga, garam tidak terjual dan pendapatan berkurang.

Setelah dampak yang terjadi masing - masing petani garam melakukan strategi adaptasi diantarnya tindakan eksternal, tindakan adaptif, dan etika subsistensi. Strategi adaptasi yang terjadi pada tingkatan buruh tani, petani garam dan pemiliki pabrik garam dalam waktu yang relatif lama dari keterpengaruhan kebijakan impor garam. Waktu dalam strategi adaptasi dibutuhkan karena berkaitan dengan self-determine pada petani garam, agar tidak salah menentukan pilihan dalam bertahan hidup dan meningkatkan taraf hidupnya. Dalam strategi adaptasi terdapat indikator yang dilakukan oleh petani garam yaitu tindakan eksternal, tindakan adaptasi, dan etika subsistensi (Umanailo, 2017). 
Petani garam dalam tindakan mengadaptasi adanya kebijakan impor garam yang tinggi ini tujuannya ialah mampu bertahan dan meningkatkan kualitas hidupnya dengan memanfaatkan berbagai elemen yang dimiliki petani garam. Ada tiga komponen kapital sosial yang dikaitkan dengan modal sosial dengan lembaga sosial yaitu jaringan sosial, norma-norma, dan kepercayaan sosial. Ketiga komponen ini akan dianalisa lebih mendalam dengan adaptasi petani garam dalam kebijakan impor garam yang tinggi. Modal sosial hendaknya dijadikan alternatif utama bentuk solusi dalam upaya mendorong pengembangan pemberdayaan masyarakat yang dapat dilaksanakan oleh seluruh pemangku kepentingan, sehingga mereka dapat lebih benar-benar berdaya, yaitu mampu menyelesaikan masalah secara mandiri (Nasdian, 2014).

Kualitas taraf hidup petani garam dalam kebijakan impor garam yang tinggi dan berdampak domino memaksa petani garam bertahan hidup dengan melakukan strategi adaptasi agar bisa bertahan hidup. Strategi adalah pola yang dibentuk oleh berbagai upaya manusia untuk menyelesaikan masalah yang ada. Strategi Petani Garam bersumber dari penjelasan Petani Garam yaitu melalui kerangka berfikir terhadap lingkungan tertentu atau kebijakan impor garam tinggi (Dharmawan, 2018).

Percaya bahwa konsep strategi adaptif mengacu pada rencana tindakan yang dirumuskan oleh kelompok tertentu atau seluruh manusia pada waktu tertentu sebagai motivasi untuk mengadopsi kemampuan internal dan eksternal. Strategi ini memiliki tingkat partisipan tertentu dalam kondisi sosial. Petani garam pada kenyataannya memiliki pernyataan tentang ide-idenya, rencana yang direncanakan dan rencana yang telah diselesaikan. Dalam situasi perekonomian yang disebabkan oleh tingginya impor garam, para petani garam harus mampu merespon dengan cepat apa yang terjadi dan harus mampu merumuskan strategi agar dapat dengan mudah menghadapi berbagai situasi yang terjadi di lingkungannya.

Petani garam dalam tindakan mengadaptasi adanya kebijakan impor garam yang tinggi ini tujuannya ialah mampu bertahan dan meningkatkan kualitas hidupnya dengan memanfaatkan berbagai elemen yang dimiliki petani garam. Ada tiga komponen kapital sosial menurut (Putnam, 2015) yang dikaitkan dengan modal sosial dengan lembaga sosial yaitu jaringan sosial, norma-norma, dan kepercayaan sosial Ketiga komponen ini akan dianalisa lebih mendalam dengan adaptasi petani garam dalam kebijakan impor garam yang tinggi. Adapun Gambar strategi adaptasi berbasis modal sosial, bisa dilihat pada Gambar 1. 


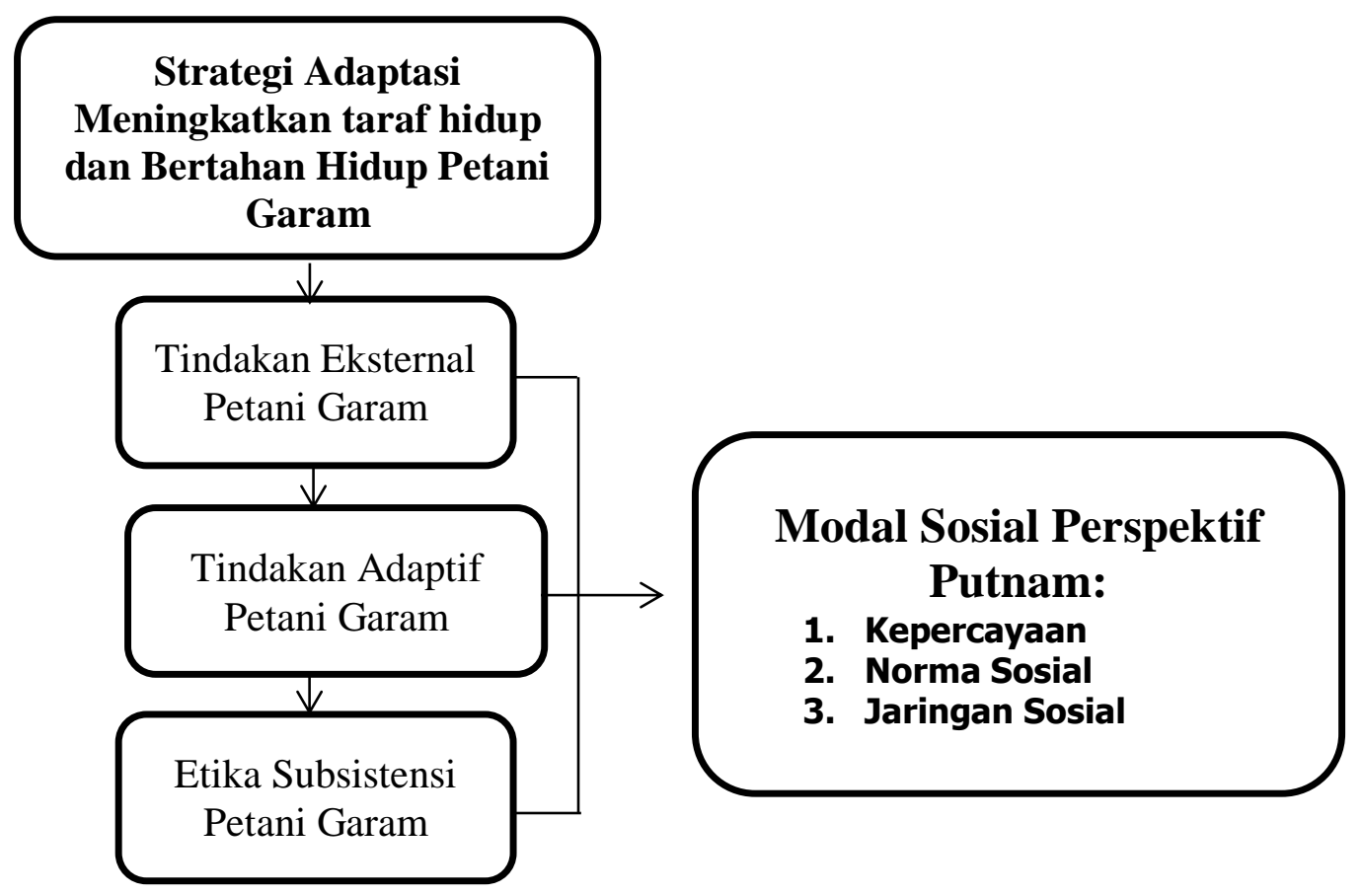

\section{Gambar 1. Strategi Adaptasi Berbasis Modal Sosial}

\section{A. Kepercayaan Dalam Strategi Adaptasi Petani Garam Dalam Kebijakan Impor Garam} Yang Tinggi

Kepercayaan pada Petani Garam merupakan bentuk kesediaan mengambil resiko dalam hubungan sosial yang dilandasi oleh keyakinan bahwa orang lain akan melakukan sesuatu sesuai dengan yang diharapkan. Dalam kehidupan sehari-hari, mereka selalu bertindak dengan sikap yang saling mendukung, setidaknya orang lain tidak akan merugikan diri sendiri dan kelompoknya (Putnam, 2015).

Fukuyama, mengemukakan bahwa unsur terpenting dalam modal sosial adalah kepercayaan yang merupakan unsur merekatkan bagi langgengnya kerjasama dalam petani garam di Desa Rawaurip, kecamatan Pangenan, Kabupaten Cirebon. Rasa percaya itu tumbuh dan berakar dari nilai-nilai yang melekat pada budaya yang ada dimasyarakat.

(Fukuyama, 2002) membagi serangkaian kebudayaan negara-negara di dunia secara dikotomis, diantaran, Pertama, high trust society (masyarakat dengan tingkat trust yang tinggi), kedua, low trust society (masyarakat dengan tingkat trust yang rendah). Masyarakat yang tergolong high trust adalah masyarakat dengan radius of trust yang panjang (lebar). Masyarakat yang tergolong low trust adalah masyarakat dengan radius of trust yang pendek (sempit).

Dengan kepercayaan antar petani garam dengan lingkungannya (saudara, tetangga dan teman - temanya) akan bisa bekerjasama secara lebih efektif dan saling membantu dalam bertahan hidup dan meningkatkan kualitas hidup. James Coleman percaya bahwa sistem yang dibentuk oleh rasa saling percaya adalah bagian yang sangat penting dari modal sosial dan dasar dari kewajiban dan harapan di masa 
depan. Bagi Putnam, ia lebih percaya bahwa trust atau mutual trust merupakan sumber kekuatan modal sosial yang dapat menjaga dinamika perekonomian dan kinerja pemerintahan yang efektif.

Kepercayaan yang dibangun oleh petani garam dalam menghadapi dampak kebijakan impor garam sangat bergantung pada kemampuan individu menciptakan kepercayaan tersebut. Dua hal yang dihadapi petani garam antara bertahan hidup dan meningkatkan kualitas hidup, menjadi tujuan minimal dan maksimal yang akan dicapai melalui tingkat kepercayaan petani garam pada lingkaran hidup disekitarnya.

Peningkatan unsur modal sosial lainnya bisa meningkat karena ada kepercayaan yang dibangun oleh petani garam dengan individu lain. Kepercayaan mampu menyediakan masyarakat untuk saling bekerjasama dan saling membantu ketika keadaan sulit. ketika keadaan yang tertekan. Ketika harga garam Rp. 200,- di level buruh tani yang berdampak pada kehidupan mengalami chaos untuk bertahan hidup. Kepercayaan yang dibangun ini akan menjadi modal awal petani garam dalam mengarungi hidup pada kebijakan impor yang tinggi ini. Adapun gambaran lebih detail kepercayaan pada masing - masing tingkat petani garam, lihat tabel 2 .

Tabel 2. Kepercayaan Petani Garam

\begin{tabular}{|c|c|c|}
\hline $\begin{array}{c}\text { Klasifikasi Petani } \\
\text { Garam }\end{array}$ & Konstruksi Kepercayaan & Sifat Kepercayaan \\
\hline Buruh Tani Garam & $\begin{array}{l}\text { Mematuhi petani garam dan } \\
\text { juragan (pemilik sawah, } \\
\text { tengkulak dan pembeli tanah) }\end{array}$ & $\begin{array}{l}\text { Kepercayaan Rendah (low- } \\
\text { trust) }\end{array}$ \\
\hline $\begin{array}{l}\text { Petani Garam yang } \\
\text { Memiliki } \quad \text { Tambak } \\
\text { Garam }\end{array}$ & $\begin{array}{l}\text { Membangun kepercayaan } \\
\text { dengan teman kerja dan toko } \\
\text { - toko klontonga }\end{array}$ & $\begin{array}{l}\text { Kepercayaan Sedang (Middle- } \\
\text { Trust) }\end{array}$ \\
\hline $\begin{array}{l}\text { Petani Garam yang } \\
\text { memiliki } \\
\text { garam }\end{array}$ & $\begin{array}{l}\text { Adanya transparansi kualitas } \\
\text { garam dengan menjual } \\
\text { melalui media sosial, keluar } \\
\text { pulau dan investasi usaha } \\
\text { baru }\end{array}$ & $\begin{array}{l}\text { Kepercayaan Tinggi (High- } \\
\text { Trust) }\end{array}$ \\
\hline
\end{tabular}

Sumber : Dianalisis oleh peneliti (2020)

\section{B. Norma dalam strategi adaptasi petani garam dalam kebijakan impor garam yang tinggi}

Petani garam dalam masyarakat harus mampu secara sukarela mencapai tujuan bersama dan mematuhi aturan yang berlaku. Karena norma sangat berperan penting dalam mengatur pada garam dalam suatu kelompok, maka keuntungan yang diperoleh setiap petani garam dapat hasil yang proporsional dengan usaha kelompoknya.

Modal sosial menurut (Fukuyama, 2002) merupakan suatu norma informal yang bersifat instan dan dapat menjalin hubungan kerjasama antara petani garam, petani garam pemilik tambak, dan pemilik pabrik garam. Norma sebagai bagian dari modal 
sosial dapat didasarkan pada norma dan etika yang disepakati antara petani garam. Selain itu, terbentuknya rasa percaya, norma dan komunitas sosial yang erat kaitannya dengan modal sosial. Sehingga modal sosial muncul dari gagasan bahwa modal sosial muncul di kalangan petani garam.

Pada petani garam kepercayaan dan norma sangat erat dalam berstrategi adaptasi. (Fukuyama, 2002; 24) mendefinisikan kepercayaan adalah norma-norma dibagangun dan disepakati bersama yang dianut oleh petani garam seperti kejujuran dan kesediaan. Jika petani garam itu mengharapkan petani garam lain bertindak jujur dan transparan, sehingga mereka akan menciptakan kondisi saling mempercayai satu sama lain. (Fukuyama, 2002) mengatakan bahwa kepercayaan adalah dampak dari suatu hal sangat penting dari norma-norma sosial yang kooperatif yang memunculkan modal sosial dalam strategi adaptasi petani garam.

Buruh tani garam dan petani garam menjalin hubungan dengan mengedepankan norma yang disepakati bersama. (Hafizh, 2017) Dalam beradaptasi harus bisa menyesuaikan diri dengan lingkungan (Autoplastis), petani garam melakukam strategi adaptasi terdapat norma yang disepakati antara buruh tani dan petani garam. Terdapat dua kesepakatan ketika harga garam murah yaitu sistem penjualan dengan bagi hasil dan negosiasi. Hal ini merupakan simbiosis mutualisme bagi keduanya, karena buruh tani yang merupakan level terbawah dari petani garam yang mengolah tambak garam mendapatkan $60 \%$ penghasilan. Namun dengan harga garam yang murah pada masa ini, sulit untuk meningkatkan taraf hidupnya. Maka negosiasi merupakan aturan yang disepakati bersama, karena dengan negosiasi menguntungkan pemilik tambak garam agar buruh tani tetap setiap menggarap garam di masa depan nanti.

Sedangkan, petani garam yang memiliki pabrik garam merupakan level yang sudah cukup profesional dalam menjalankan transaksi jual beli garam. Memiliki norma yang tegas dalam proses keberlangsungan pabrik garam, karena pabrik garam sudah memiliki legalitas seperti Persekutuan Komanditer (CV). Fakta sosial yang mengharuskan petani garam ini melakukan tindakan adaptif dalam kebijakan impor garam yang tinggi ini, karena garam impor lebih diminati dan terima di pulau jawa. Sehingga harus mengadaptasi menjual ke luar pulau jawa, dengan demikian kepercayaan pada orang baru dikenal berbasis transparansi barang yang memiliki kualitas dan harga yang baik. Menjadi norma yang disepakati bersama oleh petani garam yang memiliki pabarik di masa kini.

\section{Jaringan Sosial dalam strategi adaptasi petani garam dalam kebijakan impor garam yang tinggi}

Adanya jaringan sosial dengan norma-norma yang terkait dan kepercayaan. Ketiganya saling mendukung guna mencapai keberhasilan di bidang ekonomi antar petani garam. Jaringan sosial ini sangat berkaitan dengan strategi adaptasi petani garam guna bertahan hidup dan meningkatkan kualitas hidup. (Fukuyama, 2002) berpendapat bahwa melalui ikatan persahabatan dan kekeluargaan dapat dibangun 
jejaring untuk memberikan alternatif cara pertukaran informasi antar petani garam. Dibandingkan dengan jaringan kepercayaan rendah, jaringan kepercayaan tinggi memberikan lebih banyak manfaat dalam menghadapi kondisi sosial tersulit (Field, $2010 ; 103)$.

Bagi para petani garam, jaringan sosial merupakan media untuk menanamkan dan menyebarkan kepercayaan yaitu nilai-nilai positif untuk kelangsungan hidup agar masyarakat dapat mengembangkan hubungan yang saling menguntungkan (peer-to-peer relationship). Menjelaskan bahwa jejaring sosial tercipta dari adanya komunikasi yang terjalin dan terjalin antar individu. Fokus komunikasi intensif dan kontinuitas adalah pertukaran informasi untuk mencapai tujuan bersama, kesepakatan bersama dan saling pengertian.

Buruh tani meminjam uang pada "Bank Harian" dan negosiasi sistem pembagian merupakan bentuk interaksi intensif dan kontinuitas dengan individu lainnya. Interaksi yang tercipta dengan berlandaskan norma dan keperayaan yang dibangun oleh buruh tani garam, objek dari kedua hal tersebut ialah jaringan sosial. Dalam realitasnya buruh tani memanfaatkan anggota masyarakat dan juragan dalam membangung kesapakatan bersama dan pengertian bersama. Ditambahlagi, bekerja diluar sektor garam dalam tindakan eksternal buruh tani garam, jaringan sosial memegang peran utama karena input utama informasi pekerjaan terdapat pada jaringan tersebut. Pertemanan menjadi sentral bagi buruh tani garam dalam meningkatkan taraf hidup di tengah harga garam yang murah ini.

Petani garam yang memiliki tambak garam melakukan tindakan adaptif dengan mencari tengkulak agar bisa menjual garam dengan cepat. Tindakan eksternal yang dilakukan, petani garam mencoba usaha kecil - kecilan yang memanfaatkan lahan yang dimiliki yaitu budidaya ikan dan ternak ayam. Dalam tindakan adaptif petani garam membutuhkan kontak terhadap tengkulak yang merupakan teman pada masa lalu. Pemenfaatan ini dengan asas pertemanan garam hasil panen yang banyak menumpuk di gudang bisa dijual dengan cepat. Dalam keadaaan ini dengan jaringan yang dimiliki petani garam memperlihatkan adanya suatu ikatan jaringan memudahkan seseorang untuk mengetahui ketersediaan suatu pekerjaan. Tindakan eksternal yang dilakukan dengan bercengkrama diluar individu yang berada pada sektor garam. Merupakan tantangan bagi petani garam dalam mengembangkan usaha budidaya ikan dan ternak ayam.

Jaringan sosial bagi petani garam yang memiliki pabrik garam merupakan wadah pertukaran informasi informal dan mobilisasi sumber daya. Jaringan komunikasi memainkan peran penting dalam tindakan adaptif yang melakukan ekspansi pasar keluar pulau dan tindakan adaptif yang melakukan investasi pada sektor bidang lain. Cara untuk transmisi ide dan pengetahuan yaitu melalui jaringan perdagangan garam yang berdasarkan kelompok klik petani garam dan koperasi garam. Disisi lain, penjualan garam kemasan dan krosok skala industri memainkan 
peran jaringan dengan masyarakat luas, seperti toko klontongan, agen resmi dan pasar.

Raditasani (2020) mengungkapkan bahwa pentingnya komunikasi antar petani garam dari berbagai level ini berdasarkan ikatan informal yang spontan, fleksibel, diantara petani garam yang dituntun dengan perasaan dan kepentingan pribadi yang tidak dapat dipertahankan oleh kegiatan formal. Hal ini karena lembaga formal yang mendukung secara membumi belum begitu terlihat di Desa Rawaurip, Kecamatan Pangenan, Kabupaten Cirebon.

\section{Kesimpulan}

Berdasarkan hasil dan pembahasan yang telah penulis jelaskan dalam pembahasan, maka dapat disimpulkan bahwa: (1) Petani garam berdasarkan klasifikasi yang berbeda, dalam melakukan strategi adaptasi atas dampak sosial akibat kebijakan impor garam yang tinggi. Melakukan beberapa tindakan diantaranya tindakan eksternal, tindakan adaptif dan etika subsistensi. (2) Ada tiga komponen yang dikaitkan dengan modal sosial dengan strategi adaptasi yang dilakukan petani garam yaitu jaringan sosial, norma-norma, dan kepercayaan sosial. (3) Setelah dampak yang terjadi masing masing petani garam melakukan strategi adaptasi diantarnya tindakan eksternal, tindakan adaptif, dan etika subsistensi. Strategi adaptasi yang terjadi pada tingkatan buruh tani, petani garam dan pemiliki pabrik garam dalam waktu yang relatif lama dari keterpengaruhan kebijakan impor garam. Waktu dalam strategi adaptasi dibutuhkan karena berkaitan dengan self-determine pada petani garam, agar tidak salah menentukan pilihan dalam bertahan hidup dan meningkatkan taraf hidupnya. Dalam strategi adaptasi terdapat indikator yang dilakukan oleh petani garam yaitu tindakan eksternal, tindakan adaptasi, dan etika subsistensi. (4) Petani garam dalam tindakan mengadaptasi adanya kebijakan impor garam yang tinggi ini tujuannya ialah mampu bertahan dan meningkatkan kualitas hidupnya dengan memanfaatkan berbagai elemen yang dimiliki petani garam. Ada tiga komponen yang dikaitkan dengan modal sosial dengan lembaga sosial yaitu jaringan sosial, norma-norma, dan kepercayaan sosial. Ketiga komponen ini akan dianalisa lebih mendalam dengan adaptasi petani garam dalam kebijakan impor garam yang tinggi.

Modal sosial hendaknya dijadikan alternatif utama bentuk solusi dalam upaya mendorong pengembangan pemberdayaan masyarakat yang dapat dilaksanakan oleh seluruh pemangku kepentingan, sehingga mereka dapat lebih benar-benar berdaya, yaitu mampu menyelesaikan masalah secara mandiri. 


\section{Bibliography}

Azizah, A. N., Budimansyah, D., \& Eridiana, W. (2017). Bentuk Strategi Adaptasi Sosial Ekonomi Masyarakat Petani Pasca Pembangunan Waduk Jatigede. SOSIETAS, 7(2).

Coleman, J. S. (2011). Dasar-Dasar Teori Sosial: Referensi bagi Reformasi, Restorasi dan Revolusi. Bandung: Nusa Media.

Creswell, J. W. (2016). Research design: pendekatan metode kualitatif, kuantitatif, dan campuran. Yogyakarta: Pustaka Pelajar, 5.

Dharmawan, D. S. (2018). Strategi Bertahan Hidup Petani Garam Di Desa Pinggirpapas Kecamatan Kalianget Kabupaten Sumenep. University Of Muhammadiyah Malang.

Field, J. (2010). Modal sosial. Yogyakarta: Kreasi Wacana.

Fukuyama, F. (2002). Trust: kebajikan sosial dan penciptaan kemakmuran. Language, $19(563 \mathrm{p}), 24 \mathrm{~cm}$.

Hafizh, C. A. (2017). Mekanisme Adaptasi Korban Phk di Kota Surabaya. Universitas Airlangga.

Helmi, A., \& Satria, A. (2013). Strategi adaptasi nelayan terhadap perubahan ekologis. Hubs-Asia, 10(1).

Nasdian, F. T. (2014). Pengembangan masyarakat. Yayasan Pustaka Obor Indonesia.

Putnam, R. D. (2015). Bowling alone: America's declining social capital. Routledge.

Sugiyono, P. D. (2013). Metode penelitian manajemen. Bandung: Alfabeta, CV.

Umanailo, M. C. B. (2017). Marginalisasi Buruh Tani Akibat Alih Fungsi Lahan. 